\title{
What to Know before Entering the Great China?-A Foreign Investors’ Perspective!
}

\author{
Syeda Asiya Zenab Kazmi, Marja Naaranoja, Josu Takala
}

Faculty of Technology, University of Vaasa, Vaasa, Finland

Email: asiyakazmi@hotmail.com,marja.naaranoja@uwasa.fi,josu.takala@uwasa.fi

Received July $31^{\text {st }}, 2013$; revised August $31^{\text {st }}, 2013$; accepted September $10^{\text {th }}, 2013$

Copyright (C) 2013 Syeda Asiya Zenab Kazmi et al. This is an open access article distributed under the Creative Commons Attribution License, which permits unrestricted use, distribution, and reproduction in any medium, provided the original work is properly cited.

\begin{abstract}
This review article aims to explore options of entering in China with a foreign direct investment (FDI) motive. With an attempt to investigate the FDI possibilities in China, the paper highlights key areas including, i.e., the determinants of FDI in China, various related entry modes, the logic and criteria for making suitable FDI Location choice in China etc. The findings of the paper offer extensive foresight on the popular FDI modes to enter China with pros and cons attached to the international investment venture.
\end{abstract}

Keywords: Foreign Direct Investment; Modes of FDI; Direct Investor; Equity Joint Venture; Wholly Owned Subsidiary

\section{Introduction}

China has undoubtedly attracted huge foreign investment during the past few decades. The country first made its mark in the late 1970s with the exception of its low cost resources and strong infrastructure, in addition to its geographic location. Since then, the country never lost its pace in economic race and emerged as a strong Asian market force competing, head to head with the global super powers. In brief, China's open-door policy first initiated in 1979 followed by its seven years continued dominance as the world's second largest FDI recipient behind the United States. Till the end of May 2000, contractual FDI in China totaled at $\$ 632.3$ billion in 349,500 investment ventures, with actual investments of $\$ 320.6$ billion. Finally China became the largest recipient of foreign direct investment after touching $\$ 59.1$ billion level mark and strongly replacing United States figures which managed $\$ 57.4$ billion of FDI, during the second quarter of 2012 [1].

The above facts and figures made the authors convinced on the potentials of the Chinese location and in their report they tried to investigate the concept and future opportunities of foreign direct investment (FDI) in China. The study aims at creating an insight over the future possibilities related to FDI in China, especially through the mode equity joint venture (EJV) in business.
Furthermore, the report also touched variety of factors, contributing to the success of FDI strategy in China. The above referred factors include; the status of FDI in China in terms of determinants of FDI, other entry modes, FDI Location choice etc. In the report, an additional attempt is made to explain few key points relating to joint venture partner selection and FDI venture management with specific reference to China as the study location. The report ends with a discussion on current FDI performance pattern in China.

\section{Theoretical Background}

\subsection{Foreign Direct Investment}

FDI stands for Foreign Direct Investment. Foreign direct investment is defined as an investment of foreign assets into domestic structures, equipment, and organizations. Furthermore, in China, FDI is alternatively termed as RFDI; (R stands for Renminbi i.e., Chinese currency) and seen as export-oriented activity. In 2003 alone, the export figures by the foreign invested firms in China, touched $\$ 240.3$ billion mark, which accounted for approximately $55 \%$ of China's total exports of $\$ 438$ billion. China has principal attractions like low-cost labor and an enormous domestic market of more than 1.2 billion consumers. In the 1980s, foreigners were restricted to export-oriented joint ventures with Chinese firms. In the 
early 1990s, they were allowed to manufacture goods for sale in the domestic Chinese market; and by the mid1990s; the establishment of wholly foreign-owned enterprises was permitted [2]. China's accession to the WTO forces the government to open up the services sector.

\subsection{Popular Entry Modes to China}

Foreign investors are generally free to choose their mode of entry into the Chinese market through anyone among the following options [3]:

Foreign investors can take any option of entry mode (Table 1) in accordance to their business requirements as well as venture feasibility.

Since the late 1980s, EJVs and WFOEs have predominated over all other types of FDI, totaling up to approximately 80 percent of the total foreign capital inflows into China. However, the last several years have seen a rapid proliferation of WFOEs.

\subsubsection{Equity Joint Venture (EJV)}

Equity Joint venture involves sharing business equity as well as the risks in addition to participating in management operations between partners (i.e., individual or legal entities) to establish a continuing and profitable corporate relationship. An international joint equity venture indicates that one or more of the partners is/are foreign nationals, [4].

In all joint equity ventures, a critical question is the level of equity held by the different parties. This is typically seen as a deciding factor in who has control over the joint venture operation. For many investors, 51 per cent equity means control, whereas 50:50 means equal power for partners [5]. In general, the purpose of an IJV is to put together complementary resources of already existing firms. Thus such resources normally comprise not only ordinary financial, technical, human resources in addition to the intangible resources like goodwill, technical know-how, team spirit and similar intangible assets [6]. In the current global marketplace, strategic alliances in the form of international joint ventures have become a popular mode for entering foreign markets. However, the higher costs and risks involved in undertaking R \& D, production, financing and market penetration have

Table 1. List of popular investment entry modes to China.

\begin{tabular}{cc}
\hline Sr. No. & Modes of entries to China as Foreign investors \\
\hline $\mathbf{1}$ & Equity joint ventures (EJVs), \\
$\mathbf{2}$ & Wholly foreign-owned enterprises (WFOEs), \\
$\mathbf{3}$ & Contractual (or cooperative) joint ventures (including \\
$\mathbf{4}$ & licensing and technology transfer agreements), \\
$\mathbf{5}$ & Joint exploration, \\
\hline
\end{tabular}

brighten the prospects for expanded strategic alliances between global companies. In general, the top management of IJV believes that no organization can manage all of the high risks associated with the transnational business ventures by itself.

\subsubsection{Joint Venture Partner Selection}

The success of an equity joint venture depends on the proper selection of a venture partner. In China, few significant factors that must be taken into consideration while selecting a joint venture partner are as follows:

- Size of the partner company and its financial capabilities.

- Partner's complementary value (i.e., market share, market knowledge, customer base, technology competence, established distribution networks etc. are important factors)

- Element of trust

- The location of the partner's company.

In addition to the above factors, strategic, operational, and cultural fit of the partner, the complementarity of the partner, and compatibility of both parties in creating joint value for the investment venture are the key areas to be taken into consideration while selecting a joint venture partner in China. The success of an international equity joint venture depends principally on the appropriateness and fitness of the partners towards each other with regards to their business relationship [7]. The fitness criteria for the selection of a joint venture partner are emphasized below;

1) Strategic fit-It is a degree to which a potential alliance partner augments or compliments a partner's strategy. Strategic fitness aspect includes non-conflicting corporate strategies, absence of hidden competitive advantages, and combined opportunity which is greater than that offered if one is to go it alone. Strategic fit requires all partners to have similar resources and capabilities and to contribute the amount of resources and capabilities required [7].

2) Operational fit-Operational fit includes the elemsents like compatibility of processes, information systems, location of facilities, profitability and cash flows. In order to derive value from strategic alliances, partners must have compatible systems, procedures and technologies that can fit or work together [7]. The significance of potential synergies through potential partners is one of the significant criteria for operational fit as well to evaluate the suitability of the alliance partners [8].

3) Cultural fit-It refers to the corporate culture as well as the national culture fit. Corporate culture fit is the compatibility between partner firms as reflected through the organizational management style. This includes the levels of employee participation, management operations, delegation of responsibility, and centralized or decen- 
tralized decision-making processes. While considering corporate culture the issues such as ethics responsiveness to change, and corporate governance take the center stage. The degree of compatibility of the organizational culture, the potential of the partners determines the joint venture's significance [7]. In addition, the significance of cultural compatibility for venture alliance effectiveness is noticed as highly important [8].

\subsubsection{Location Choices for FDI in China}

The search for a better investment location to realize the external comparative advantages and to save costs are the main objectives for the FDI firms before entering to any new country. In addition, to the already discussed lucrative strategies (e.g., entering China through Hong Kong as a quick and less expensive option etc.), there are various other options available to enter China through the locations like Hong Kong's neighboring province, Guangdong and the Pearl River Delta (PRD) region in the vicinity [9], have their own advantages which were extensively opted since 1980 s.

The potential determinants of FDI location can be studied through the research work conducted by numerous worthy researchers [10-24]. On the basis of the researchers' feedback on the topic, below is the list of the factors influencing FDI Location choices [20] and a Table 2 reflecting theoretical support on the topic:

- Easy market accessibility: It relates to factors namely; Competitors, customers, transportation issues etc.

- Attractive labor costs: This relates to the cost incurred on the manpower while firm's production operations,

- Availability of suitable Infrastructure: This includes the issues related to machinery and building etc.

- Government FDI friendly policies: It involves the key concerning areas like Quota, Taxations etc.

- Agglomeration effects: It includes all those factors that support and assist the firms to be clustered together at the geographical location where the economic activity is strong.

A theoretical support for the numerous FDI entry modes on the basis of theoretical support (Table 2) is strengthening the concept's applicability.

Chinese Government remained very consistent in introducing supportive FDI location choices in China [2]. A brief overview on the above is in Table 3 .

Table 3 presents a brief summary of the Chinese Governments initiatives to encourage foreign investment in the country.

\subsubsection{Advantages of International Joint Equity Venture in China}

In international equity joint venture, the political and commercial risks involved are less unlike sole venture. The host country officials are not eager to nationalize or to confiscate the firm if it is partly owned by locals especially, especially if linked to the government in some form. The Local market knowledge, culture, experience, and access to technology and cheap labor, distribution network, customer knowledge, mastery of customs, language etc. brought by a local partner may be of utmost importance for the business development and success. Recruitment of labor and other staff is easier through the local partners; leadership or management of the firm is easier to perform with the help of a local partner. A local firm may bring valuable adjusted and appropriate technological knowledge/skills [4].

\subsubsection{Disadvantages of Joint Equity Venture in China} The objective of the local partner may be different from those of the mother firm. Nepotism and bias by the joint venture's partner about the mother firm's vested interests in controlling the monetary flows and crucial decision making is possible. Less profit and lack of cooperation is possible, unlike in wholly owned subsidiary. This may have negative impact on the joint venture business. High opportunistic risks and the lack of trust is another weakness of a joint venture depending on the partner. The partner may take advantage of the business to copy the partner's know-how, style, and technology for his own personal interest [4].

Table 2. List of popular investment entry modes to China with the theoretical support.

\begin{tabular}{|c|c|c|}
\hline Sr. No. & Literature support & Theorists \\
\hline 1 & $\begin{array}{l}\text { The corporate advantage of adjacent localities in addition to the market size of the host } \\
\text { region is considered to have potential effect on FDI location choices. }\end{array}$ & Head and Mayer 2004. \\
\hline 2 & $\begin{array}{l}\text { A significant part of multinational activity tends to take the form of firms shifting a part of } \\
\text { process to low-cost locations. }\end{array}$ & $\begin{array}{l}\text { Helpman, 1984, 1985; } \\
\text { Helpmanand Krugman, } 1985 .\end{array}$ \\
\hline 3 & Telecommunications infrastructure has positive linkage with the nature of production. & $\begin{array}{l}\text { Coughlin et al., 1991; Chen, } \\
\text { 1996; Cheng and Kwan, } 2000 .\end{array}$ \\
\hline 4 & $\begin{array}{l}\text { Transformation from the direct exports activities to the local production is considered as } \\
\text { a step towards cost reduction. }\end{array}$ & $\begin{array}{l}\text { Horstman and Markusen, 1987; } \\
\text { Markusen and Venables, } 1999 .\end{array}$ \\
\hline 5 & $\begin{array}{l}\text { Government policy has generally been viewed as a key variable that can attract FDI and } \\
\text { alter FDI flows across regions. }\end{array}$ & Lunn, 1980. \\
\hline 6 & Agglomeration effects are considered as the result of sanguine linkages among projects. & Fujita et al., 1999. \\
\hline
\end{tabular}


Table 3. The trend of FDI investment actually started to surge in mid. 1980 due to the governments following initiatives.

- At first China adopted its open door policy in 1978

- Acknowledgement of “Open Coastal Cities” for FDI in 1984.

- Establishment of Economic and Technology Development Zones (ETDZs) for FDI.

- Establishment of 05 Special Eco. Zones (SEZs) till 2002 i.e., three Zones in Guangdong, one in Fujian and one in Hanian Province.

- Introduction of Open Coastal Areas for FDI.

- Technical and Industrial Development Zones were established to support FDI.

- Bonded Zones were established for FDI.

- Border Economic Cooperation Zones were established to support FDI.

- Export Processing Zones were established.

*China's potential market size, low labor cost, preferential policies (e.g., tax credits), openness, geographic proximity, and political stability as primary factors attracting FDI.

\subsubsection{Wholly Owned Subsidiary (Sole Venture)}

Wholly owned subsidiary or a sole venture is when a firm establishes a presence in a foreign country either through buying an existing company (acquisition strategy) or through building a unit from scratch. A subsidiary is fully owned by the mother firm unlike joint venture, which is partially owned by the mother and by one more local/domestic/third country private partner companies or partners. The mother firm may be an industrial firm or non-industrial, service firm [5]. A wholly owned subsidiary is when a company sets up a new venture in which it owns $100 \%$ of its stocks [25]. A unit to be es0 tablished by an industrial firm may be: a sales promotion unit, warehouse unit, R \& D unit, technology transfer unit, manufacturing unit, financing unit, holding unit, or an assembly unit. In a wholly owned subsidiary, 100 percent of this new subsidiary's stock is owned by the parent firm. It is entirely owned by its holding company and all the voting for a wholly owned subsidiary is done by the parent company and/or its other subsidiaries.

\subsubsection{Advantages of a Wholly Owned Subsidiary in China}

Traditional direct investment methods, such as setting up wholly-owned subsidiaries offer the benefits of total profits and full control over the foreign subsidiary. However, the higher costs and risks involved in undertaking R \& D, production, financing and market penetration brighten the prospects for expanded strategic alliances between global companies as top management believes that no organization alone can manage all of the high risks associated with transnational ventures

\subsubsection{Disadvantages of the Wholly Owned} Subsidiaries in China

In China, the biggest disadvantage of a wholly owned subsidiary is that it is very expensive to run the business operations without a local partner. It is actually the most expensive mode of entry choice in terms of investment capital. When choosing a wholly owned subsidiary, the firm will have to bear all of the costs of setting up the operation. If the firm chooses an established firm to promote its products, trying to "marry" the two cultures (i.e., the host country and the home country) may collide. The consequences may outweigh the advantages of WOS. Choosing a wholly owned subsidiary, especially green field is an expensive and difficult entry strategy to China because usually no firm alone can manage all of the high risks associated with this modality [25].

\subsection{The Determinants of FDI in China}

Foreign direct investment represents special form of capital flows involving not only the location and capital etc. but intangible assets as well such as production know-how, management skills and multinational enterprises as the major players of FDI.

National characteristics, including economic growth rates, labour costs, availability of skilled labour and technology, government regulations, open policy for FDI and topographical characteristics can affect the success of FDI in addition to the list of key determents mentioned in Table 4.

In addition, socio-cultural, economic and political conditions create boundaries among different countries. Such factors are significant determinants of MNEs decision making with regards to their overseas activities; there is reason to believe that regional distinctions within countries may influence the location of FDI decisions [26].

Table 4. Key determinants of FDI in China.

\begin{tabular}{|c|c|}
\hline Sr. No & Prominent determinants of FDI in China are; \\
\hline 1 & $\begin{array}{l}\text { Market size as well as the GDP of the host country } \\
\text { (i.e., China is an example for being the fasted growing } \\
\text { economy in the world) }\end{array}$ \\
\hline 2 & Flexibility towards foreign direct investment \\
\hline 3 & China's WTO membership, \\
\hline 4 & Attractive currency exchange rates, \\
\hline 5 & Foreign investment friendly Tax policy, \\
\hline 6 & Obvious economic growth potential, \\
\hline 7 & $\begin{array}{l}\text { Availability of raw materials, economical skilled labor, } \\
\text { technology and infrastructure, }\end{array}$ \\
\hline 8 & $\begin{array}{l}\text { Geographical location/ the proximity of China in the } \\
\text { region, }\end{array}$ \\
\hline 9 & Political Stability. \\
\hline
\end{tabular}


China's institutional reforms and its continuous improvements initiatives for creating desirable investment environment are among other external global factors that have played significant role in attracting FDI into China during 1980 and 1992. Institutional reform and FDI inflows enhanced supported each other mainly in Guangdong which was first designed and opened up as a showroom to receive FDI. Cities such as Shenzhen, Dongguan, Zhuhai, where foreign manufacturing firms started landing as investors, rapidly urbanized through FDI-driven export-led economic growth. Since 1992, with the introduction of refined fundamental economic policy in China, more diversified FDI flew into PRD, especially including from Europe and U.S.A. in addition to the two overseas Chinese economies i.e., Hong Kong/Macau and Taiwan [27].

List of numerous factors contributing to EJV problems (Table 5) have been identified, but the primary fact stems from the joint ownership mismatch, especially involving joint venture management pattern such as; two or more parent firms' collaboration.

\subsection{Analysis of the Entry Modes to China}

Different firms have different reasons for internationalization of their business operations or investment activities. Some are seeking new outlets for their products and know-how outside their home markets while others are seeking expansion of capital and new technology not available in their own countries. Product characteristics are expected to influence the export channel decision by dictating the need for control of the marketing and merchandising program in the host country [28].

However, each one of the entry mode, discussed in this report has different implications with reference to the degree of command and control which a firm can exercise over the foreign operation, the resources it must commit to the foreign operation, and the risks that it must bear to expand within a foreign country. Thus, the performance of one investment mode in relation to the other is a critical measure of its relative efficacy and would directly affect each other's choice [25].

Henceforth, from the perspective of effective control and high profit margin, wholly owned subsidiary is appropriate, but the cost and the risk involved is high due to the of lack of command over Chinese language, culture,

Table 5. List of Reasons for recent shift in FDI entry modes.

\begin{tabular}{cl}
\hline Sr. No. & \multicolumn{1}{c}{$\begin{array}{c}\text { Reasons of recent shift in entry modes } \\
\text { from WFOEs to EJVs }\end{array}$} \\
\hline 1. & $\begin{array}{l}\text { The substandard past performance experiences of } \\
\text { numerous EJVs during the recent past, }\end{array}$ \\
2. & The inherent advantages of WFOEs, \\
3. & Alterations in the government regulations \\
4. & An uncertain environment. \\
\hline
\end{tabular}

market know-how and the local regulation. In China, building relationship (i.e., termed as guanxi in local language), is highly important since without having the connection or an active local partner it's extremely challenging to operate in the local business scene.

The cost of establishing and managing a wholly owned subsidiary is really high unlike Joint venture, though the profit margin is significantly higher, if the business succeeds. International joint venture provides a firm with less cost of establishment, effective, efficient and quick market penetration, though the opportunistic risk is high as well, depending on the partner's selection.

Different companies pursue different things in their internalization objectives [6]. Some are seeking new outlets for their products and know-how outside their home markets while others are seeking capital expansion and new technology which unavailable in their own countries. In order to achieve these goals, a firm must determine appropriate mode for organizing its foreign business activities. Among the vast array of alternative modes available, international joint ventures (IJV) and wholly owned subsidiaries (WOS) represent two primary but largely competing strategic options that a firm may choose. Each of these strategies has different implications for the degree of control which a firm can exercise over the foreign operation, the resources it must commit to the foreign operation, and the risks that it must bear to expand into a foreign country. On the basis of this analysis and the entire report equity joint venture (EJV) is the most appropriate efficient mode of FDI to China.

\section{Business Entry Strategies to China}

There are two popular ways of entering into China's most potential and lucrative business market, which are as follows:

1) Entering China through Hong Kong distributors

The option of entering into China's business market through Hong Kong distributors involves few concerns which are included in the following list:

Only the correct and balanced settlement on all the above questions can guarantee the success of business decision of a foreign investor. Though the option of entering China via Hong Kong apart from few concerning points (Table 6), is an attractive option but it has its own pros and cons that are summarized as below:

An instant guide (Table 7) reflects the comparative option stand points for the FDI entry to China through Hong Kong.

2) Market entry via direct channels in China. The option to enter Chinese business market by the foreign investor is to use direct channels which are listed as follows:

- Chinese foreign trading corporations (FTCs)

- Industrial trading corporations (ITCs) 
Table 6. Hong Kong as foreign investor list of key concerns while entering China through Hong Kong.

\begin{tabular}{cl}
\hline Sr. No. & Key Concerns \\
\hline a. & How to evaluate the real worth and value of the selected distributors located at Hong Kong-benefit perspective? \\
c. & Which areas they actually focus on and specialize in — potential perspective? \\
d. & What is the quality of their operational set up? \\
e. & What guarantees and assurances they offer to your business—-services perspective? \\
f. &
\end{tabular}

Table 7. A Quick over view on the pros and cons of FDI entry to China through Hong Kong.

\begin{tabular}{lllll}
\hline \multicolumn{2}{c}{ Advantages } & & & Disadvantages \\
\hline $\mathbf{1}$ & The easiest and quickest way to export & $\mathbf{1}$ & Difficulty in reaching the end users directly \\
$\mathbf{2}$ & No language barriers & $\mathbf{2}$ & Dependency on the middleman \\
$\mathbf{3}$ & No significant culture barriers & $\mathbf{3}$ & Limited knowledge of consumers' needs \\
$\mathbf{4}$ & Well established channels with Mainland & $\mathbf{4}$ & Still subject to tariffs/quotas \\
& & $\mathbf{5}$ & Issues in the provision of Post sale service
\end{tabular}

- Independent entrepreneurial third party trading companies

- Domestic end-users

- Domestic Chinese distribution companies

Any option from the above strategies can be opted, after proper brainstorming and thorough research especially, keeping in view the nature of business and the available matching options in China to pursue a business venture.

\section{Concluding Discussion}

Any foreign investment decision by a business initiator involves a great deal of courage, keeping in view the challenges attached with the options of opening up new frontiers and chasing the unknown local opportunities. This is undoubtedly a difficult option to do business anywhere in the world. However, it becomes more challenging if the foreign investment decision involves China as a target location due to the following critical factors [29]:

- The perplexing culture,

- Language barrier,

- Strong influence of Confucianism in the overall operations, including the business practices having strong key force of "guanxi",

- Non comparative governmental policies,

- Legal differences (e.g., on the areas of intellectual property, local governments regulations specifically on business practices, labor unions structure and op- erational routines, the local rules, customs regulations, taxation etc.

- Limited indigenous skilled labor availability,

- Strong competition and

- Finally the underutilized market primarily consolidating Chinese national companies.

Though China is considered a tough business location to enter as a foreign investor, the potential long-term economic opportunities attached to the option are too encouraging to restrict the investor's entry decision. Hence, the business managers of foreign firms indulge quite frequently in learning and following the options what the other foreign investors pursue to enter China. However, while pursuing their business strategies in China, the foreign investors learn to handle the socioeconomic cultural dissimilarities, but they usually describe that the way is more difficult than what they experience in any other foreign location [29].

However, with the passage of time, the tight investment conditions eased up in China through Government's investment friendly gestures. Such initiatives started with Chinese business and trade barriers in 1978. Year 1992 was seen as the turning point in China's political and economic reforms with the potential steps like Mr. Deng Xiaoping's visit to the southern provinces and his desire for accelerating economic reforms by giving green signal to initiate foreign business and trade investments. Chinese government encouraged the foreign investors through the introduction of softer trade and 
investment regulations, opening up new business zones, export promotion offices at foreign locations, local distributor's approach, and distributors in Hong Kong's role. Consequently, till the year 2012, China appeared as the top FDI recipient country after by touching $\$ 59.1$ billion level mark to replace USA. This paper aimed at providing knowledge to the foreign investors, business strategist and the students who are interested to know the direct investment in China.

\section{REFERENCES}

[1] Reuters, "China Tops U.S. as Investment Target in 1st Half 2012: U.N. Agency,” 2012.

http://www.reuters.com/article/2012/10/24/us-china-us-in vestment-idUSBRE89N0EZ20121024.

[2] Y. Xing, "Why is China So Attractive for FDI? The Role of Exchange Rates," China Economic Review, Vol. 17, 2006. pp. 198-209.

[3] D. Ping, "WFOEs: The Most Popular Entry Mode into China," Business Horizons, Vol. 44, No. 4, 2001, pp. 6372. http://dx.doi.org/10.1016/S0007-6813(01)80049-5

[4] R. Luostarinen and L. Welch, "International Business Operation," kyriiri Oy, Helsinki, Finland, 1990.

[5] L. S. Welch, G. R. G. Benito and B. Petersen, "Foreign Operation Methods: Theory, Analysis, Strategy," Edward Elger, Cheltenham, 2007.

[6] A. Chan, "The Emerging Patterns of Industrial Relations in China and the Rise of Two New Labour Movements," China Information, Vol. 9, No. 4, 1995, pp. 36-59. http://dx.doi.org/10.1177/0920203X9500900402

[7] K. Mellahi, J. G. Frynas and P. Finlay, "Global Strategic Management," Oxford University, New York, 2005.

[8] J. Child and D. Faulkner, "Strategies of Cooperation, Management Alliances, Networks, and Joint VenturesPartner and Form Selection," Oxford University Press, 1998, Oxford, pp. 88-112.

[9] L. F. Y. Ng and C. Tuan, "Location Decisions of Manufacturing FDI in China: Implications of China's WTO Accession," Journal of Asian Economics, Vol. 14, No. 1, 2003, pp. 51-72 http://dx.doi.org/10.1016/S1049-0078(02)00241-5

[10] C. C. Coughlin, J. V. Terza and V. Arromdee, "State Characteristics and the Location of Foreign Direct Investment within the United States," The Review of Economics and Statistics, Vol. 73, 1991, pp. 675-683. http://dx.doi.org/10.2307/2109406

[11] J. Friedman, D. A. Gerlowski and J. Silberman, "What attracts foreign multinational corporations? Evidence from branch plants in the United States," Journal of Regional Science, Vol. 32, 1992, pp. 403-418. http://dx.doi.org/10.1111/j.1467-9787.1992.tb00197.x

[12] D. Wheeler and A. Mody, "International Investment Location Decisions: The Case of U.S. Firms," Journal of International Economics, Vol. 33, 1992, pp. 57-76. http://dx.doi.org/10.1016/0022-1996(92)90050-T

[13] K. Head and T. Mayer, "Market potential and the location of Japanese investment in the European Union," The Review of Economics and Statistics, Vol. 86, No. 4, 2004, pp. 959-972. http://dx.doi.org/10.1162/0034653043125257

[14] S. J. Kang and H. S. Lee, "The Determinants of Location Choice of South Korean FDI in China," Japan and the World Economy, Vol. 19, 2007, pp. 441-460. http://dx.doi.org/10.1016/j.japwor.2006.06.004

[15] C. H. Chen, "Regional Determinants of Foreign Direct Investment in Mainland China," Journal of Economic Studies, Vol. 23, No. 2, 1996, pp. 18-30. http://dx.doi.org/10.1108/01443589610109649

[16] R. Barrell and N. Pain, "An Econometric Analysis of U.S. Foreign Direct Investment," The Review of Economics and Statistics, Vol. 78, 1996, pp. 200-207. http://dx.doi.org/10.2307/2109921

[17] L. K. Cheng and Y. K. Kwan, "What Are the Determinants of the Location of Foreign Direct Investment, the Chinese Experience," Journal of International Economics, Vol. 51, 2000, pp. 379-400. http://dx.doi.org/10.1016/S0022-1996(99)00032-X

[18] I. Horstman and J. R. Markusen, "Strategic Investments and the Development of Multinationals," International Economic Review, Vol. 28, No. 1, 1987, pp. 109-121. http://dx.doi.org/10.2307/2526862

[19] M. Fujita, P. Krugman and A. J. Venables, "The Spatial Economy," MIT Press, Cambridge, 1999.

[20] S. J. Kang and H. S. Lee, "Location Choice of Multinational Companies in China: Korean and Japanese Companies," Korea Institute for International Economic Policy, KEIP Working Papers 04-13, 2005.

[21] E. Helpman, "Multinational Corporations and Trade Structure," The Review of Economic Studies, Vol. 52, 1985, pp. 443-457. http://dx.doi.org/10.2307/2297663

[22] J. Markusen and A. Venables, "Foreign direct investment as a catalyst for industrial development," European Economic Review, Vol. 43, 1999, pp. 335-356. http://dx.doi.org/10.1016/S0014-2921(98)00048-8

[23] E. Helpman and P. R. Krugman, "Market Structure and Foreign Trade. Increasing Returns, Imperfect Competition, and the International Economy," MIT Press, Cambridge, 1985.

[24] J. Lunn, "Determinants of US Direct Investment in the EEC: Further Evidence," European Economic Review, Vol. 13, 1980, pp. 93-101. http://dx.doi.org/10.1016/0014-2921(80)90048-3

[25] K. O'Brien and L. Li, "Rightful Resistance in Rural China," Cambridge University Press, New York, 2006. http://dx.doi.org/10.1017/CBO9780511791086

[26] D. D. Chadee, F. Qiu and E. L. Rose, "FDI Location at the Subnational Level: A Study of EJVs in China," Journal of Business Research, Vol. 56, 2003, pp. 835-845. http://dx.doi.org/10.1016/S0148-2963(02)00471-X

[27] C. Tuan, and L. F. Y. Ng, "The Place of FDI in China's Regional Economic Development: Emergence of the Globalized Delta Economies," Journal of Asian Economics, Vol. 18, 2007, pp. 348-364.

http://dx.doi.org/10.1016/j.asieco.2007.02.005 
[28] F. Jiang, "Factors Affecting the Effectiveness of FDI Venture Operations in China: A Comparison between Early-Entrants and Late-Entrants," Journal of the Academy of Business and Economics, Vol. 2, No. 2, 2003, 29 p.
[29] A. Marino, "The Impact on FDI on Developing Countries Growth: Trade Policy Matters," Istat-Cemafi, France, 2000. 